\title{
Role of L-Thyroxine in Nuclear Thyroid Hormone Receptor Occupancy and Growth Hormone Production in Cultured GC Cells
}

\author{
Yitzchak Halperin, Lawrence E. Shapiro, and Martin I. Surks \\ Division of Endocrinology and Metabolism, Department of Medicine, Montefiore Medical Center \\ and Albert Einstein College of Medicine, Bronx, New York 10467
}

\begin{abstract}
The contribution of $L$-thyroxine $\left(\mathrm{T}_{4}\right)$ to nuclear thyroid receptor occupancy was studied in GC cells incubated with concentrations of 3,5,3'-triiodo-L-thyronine $\left(T_{3}\right)$ and $T_{4}$ that resulted in free iodothyronine levels similar to those in serum of euthyroid rats. $T_{4}$ accounted for $5.4-10 \%$ of the occupied receptors: $T_{3}$ derived from $T_{4}\left[T_{3}\left(T_{4}\right)\right]$ and $T_{3}$ added to medium accounted for the remainder of receptor occupancy. Incubation with increasing medium free $T_{4}$ resulted in a progressive increase in the contribution of $T_{4}$ and $T_{3}\left(T_{4}\right)$ to receptor occupancy. In incubations with 3.6-fold increased medium free $T_{4}, T_{4}$ accounted for $20.4 \%$, and $T_{3}\left(T_{4}\right)$ for $40.3 \%$ of receptor occupancy. These occupancy data and the experimentally determined $K_{2}$ of thyroid receptor for $T_{3}$ and $T_{4}$ allowed calculation of nuclear free iodothyronine concentrations. Nuclear free $T_{3}$ was 3-6-fold greater than medium free $T_{3}$ and medium free $T_{4}$ was 12-19fold greater than medium free $T_{4}$. When GC cells were incubated with decreased medium free $T_{3}$ and physiological medium free $T_{4}$, both nuclear receptor occupancy and growth hormone production decreased as well. However, a twofold increase in medium free $T_{4}$, in the presence of decreased medium free $T_{3}$, restored receptor occupancy and growth hormone production to or near control values. These findings establish a role for $T_{4}$ in addition to $T_{3}\left(T_{4}\right)$ in nuclear receptor occupancy and biological activity in rat anterior pituitary tissue both in physiologic conditions and when medium free $T_{4}$ is raised. The findings may have relevance to the sick euthyroid thyroid syndrome in which free $T_{4}$ may be increased in some patients who have decreased serum free $T_{3}$. (J. Clin. Invest. 1991. 88:12911299.) Key words: $L$-triiodothyronine $\left(T_{3}\right) \bullet L$-thyroxine $\left(T_{4}\right) \bullet$ nuclear free $T_{3}$ and free $T_{4} \bullet$ sick euthyroid syndrome $\bullet$ type II $5^{\prime}-T_{4}$ monodeiodinase
\end{abstract}

\section{Introduction}

L-Thyroxine $\left(\mathrm{T}_{4}\right)$ was reported in 1948 to be the circulating thyroid hormone by Taurog and Chaikoff (1). The discovery of 3,5,3'-triiodo-L-thyronine $\left(\mathrm{T}_{3}\right)$ in $1952(2)$ and demonstration that $T_{3}$ had greater biological activity than $T_{4}(3)$ led Gross and Pitt-Rivers (2) to suggest that effects of $T_{4}$ might result from

Address reprint requests to Dr. Halperin, Division of Endocrinology and Metabolism, Montefiore Medical Center, 111 East 210th Street, Bronx, NY 10467.

Received for publication 20 December 1991 and in revised form 14 April 1991.

J. Clin. Invest.

(c) The American Society for Clinical Investigation, Inc.

$0021-9738 / 91 / 10 / 1291 / 09 \$ 2.00$

Volume 88, October 1991, 1291-1299 deiodination to $T_{3}$. However, experimental methods were not sufficiently sensitive to test this hypothesis at that time $(4,5)$. Measurements of plasma $T_{3}$ became available in $1970(6)$ and investigators rapidly demonstrated that most of the extrathyroidal $T_{3}$ pool in humans and rats was generated by deiodination of $T_{4}(7-9)$. Moreover, conversion of $T_{4}$ to $T_{3}$ was required for a major portion of the apparent activity of $T_{4}(10)$. These findings and the discovery that the nuclear thyroid hormone receptor had a greater affinity for $T_{3}$ than for $T_{4}(11,12)$ suggested that $T_{4}$ was mainly a prohormone, effecting biological responses by means of generated $T_{3}$.

In euthyroid rats, $T_{3}$ that is locally generated from $T_{4}$ $\left[\mathrm{T}_{3}\left(\mathrm{~T}_{4}\right)\right]^{1}$ within brain and anterior pituitary constitutes the principal source of nuclear $T_{3}$, whereas nuclear $T_{3}$ in liver and kidney is derived mainly from exchangeable plasma $T_{3}\left[T_{3}\left(T_{3}\right)\right]$ $(13,14)$. The role of $T_{4}$ itself in occupancy of nuclear thyroid hormone receptors has not been established in anterior pituitary. Studies in euthyroid rats suggested that $T_{4}$ constituted $10-15 \%$ of the endogenous iodothyronines specifically associated with thyroid nuclear receptors in liver and kidney (15) but was not detected in anterior pituitary $(16,17) . T_{4}$ was shown to have intrinsic biological activity by Samuels et al. (18), who showed that $T_{4}$ induced growth hormone (GH) production and thyroid nuclear receptor down-regulation in $\mathbf{G H}_{1}$ cells in the absence of appreciable conversion of $T_{4}$ to $T_{3}$. More recently, others have shown that $\mathrm{GH}_{1}$ cells do generate appreciable amounts of $T_{3}$ from $T_{4}(19)$.

Because interactions between iodothyronines and nuclear thyroid receptors are considered to initiate thyroid hormone action, the foregoing studies suggest that $T_{4}$ itself effects 10$15 \%$ of the biological activity of thyroid hormones in liver and kidney. Although $\mathrm{T}_{4}$ affects biological activity in anterior pituitary by means of $T_{3}\left(T_{4}\right)$, these reports (16-19) also suggest that the role of $\mathrm{T}_{4}$ itself in thyroid hormone action in anterior pituitary is not clearly defined. The issue is important for understanding both the action of thyroid hormones under physiologic conditions and during the alterations in plasma thyroid hormone concentrations that occur in patients with nonthyroidal disease. Unlike normal individuals, patients without thyroid disease who have an acute nonthyroidal illness are characterized by a decrease in the serum free $T_{3}$ concentration and either a normal or increased concentration of the serum free $T_{4}$ (20-22). Data concerning the biological impact of the normal or raised concentrations of free $T_{4}$ in this acute clinical setting have not been reported. It is not known, for example, whether

1. Abbreviations used in this paper: $\mathrm{GH}$, growth hormone; $\mathrm{MFT}_{3}$, medium free $\mathrm{T}_{3} ; \mathrm{MFT}_{4}$, medium free $\mathrm{T}_{4} ; \mathrm{NFT}_{3}$, nuclear free $\mathrm{T}_{3} ; \mathrm{NFT}_{4}$, nuclear free $\mathrm{T}_{4}$; NS-DME, DME containing $10 \%$ normal serum; RTDME, DME containing $10 \%$ resin-treated calf serum; $T_{3}\left(T_{4}\right), T_{3}$ derived from $T_{4}$ monodeiodination; $T_{3}\left(T_{3}\right), T_{3}$ derived from medium $T_{3}$; TR, nuclear thyroid receptor. 
the high concentration of free $T_{4}$ in some patients with acute illness initiates biological activity which offsets the decrease in activity anticipated as a consequence of decreased concentrations of serum free $T_{3}$.

Because of these uncertainties, we have investigated the role of $\mathrm{T}_{4}$ in the occupancy of nuclear thyroid hormone receptors using cultured GC cells, a well-characterized rat GH-producing cell line that is responsive to thyroid hormones. We have studied nuclear thyroid hormone receptor (TR) occupancy by $T_{4}$ and $T_{3}$ during incubation of GC cells in medium which contains free $T_{4}$ and free $T_{3}$ concentrations similar to those in euthyroid rats. Studies were also done in cells maintained in medium in which free $T_{4}$ and free $T_{3}$ were altered in a manner that is similar to patients with nonthyroidal disease.

\section{Methods}

Materials. L- $\mathrm{T}_{3}, 3,5$-diiodo-L-thyronine, $\mathrm{L}_{4} \mathrm{~T}_{4}, \mathrm{D}_{-} \mathrm{T}_{3}, \mathrm{D}-\mathrm{T}_{4}$, and Dowex $1 \times 8,400$-mesh anion exchange resin were purchased from Sigma Chemical Co., St. Louis, MO. $\mathrm{T}_{4}$ was purified by paper chromatography (22). The content of $T_{3}$ in the purified $T_{4}$ was assessed by supplementing iodothyronine-depleted human serum (23) with the purified $T_{4}$ and measuring $T_{3}$ using a Clinical Assays Kit (Travenol Laboratories, Inc., Cambridge, MA). Using these methods, the purified $T_{4}$ preparations contained $<0.05 \% T_{3}$. Dulbecco's modified Eagle's medium (DME), heat-inactivated calf and horse serum, and trypsin-EDTA were purchased from Gibco Laboratories, Grand Island, NY. Iopanoic acid was purchased from Chemical Dynamics Co., South Plainfield, NJ. Reagents for measurement of rat GH by radioimmunoassay (RIA) were a gift of the National Hormone and Pituitary Program, National Institute of Digestive Diseases and Kidney, National Institutes of Health, Bethesda, MD. Carrier-free $\mathrm{Na}\left[{ }^{125} I\right]$ iodide and $\mathrm{Na}\left[{ }^{131} I\right]$ iodide were obtained from New England Nuclear, Boston, MA. ${ }^{131}{\text { I-labeled } T_{3}}_{3}$ was synthesized from carrier-free $\left[{ }^{131} \mathrm{I}\right]$ iodide and 3,5-diodothyronine, and ${ }^{125}$ I-labeled $T_{4}$ was synthesized from carrier-free $\left[{ }^{125} I\right]$ iodide and $T_{3}$ according to the methods of Kochupillai and Yalow (24). Iodothyronines were purified as previously described (22). $\left[{ }^{131} \mathrm{I}\right] \mathrm{T}_{3}$ had a specific activity of $2.13 \mathrm{Ci} / \mu \mathrm{mol}(3,280 \mu \mathrm{Ci} / \mu \mathrm{g})$ and was $>95 \%$ pure as assessed by paper chromatography (22) [ $\left.{ }^{125} \mathrm{I}\right] \mathrm{T}_{4}$ had a specific activity of 2.13 $\mathrm{Ci} / \mu \mathrm{mol}(2,750 \mu \mathrm{Ci} / \mu \mathrm{g})$ and contained $<0.1 \%$ of $\left[{ }^{125} \mathrm{I}\right] \mathrm{T}_{3}$ as assessed by paper chromatography (22). In that Freake et al. (25) reported that racemization of $\mathrm{L}_{-} \mathrm{T}_{3}$ may occur during iodination, we measured the racemic contamination of $L-\left[{ }^{125} \mathrm{I}\right] \mathrm{T}_{3}$ and $\mathrm{L}-\left[{ }^{125} \mathrm{I}\right] \mathrm{T}_{4}$ with $\mathrm{D}$-isoforms by high-performance liquid chromatography (HPLC) using the method of Hay et al. (26) (Fig. 1). $<6 \%\left[{ }^{125} \mathrm{I}\right] \mathrm{D}-\mathrm{T}_{3}$ and $<3 \%$ D- $\left[{ }^{125} \mathrm{I}\right] \mathrm{T}_{4}$ were found in the respective ${ }^{125} \mathrm{I}$-labeled preparations of the $\mathrm{L}$-isomers. Because of these results, we considered that the radiolabeled L-isomers were all in the L-form and made no corrections for the putative small degree of racemization that was observed.

Free $T_{4}$ and free $T_{3}$ concentrations in rat serum. Male CD(SpragueDawley) rats were obtained from Charles River Laboratories, Inc., Wilmington, MA. The rats were housed in a vivarium, fed Wayne Laboratory rat diet (Allied Mills, Inc., Memphis, TN), and allowed tap water ad lib. Rats generally weighed between 200 and $260 \mathrm{~g}$ at the time they were studied. After the animals had been maintained in the vivarium for at least $1 \mathrm{wk}$, groups of rats were killed by exsanguination through the abdominal aorta under light ether anesthesia. Serum was obtained by centrifugation. The animal study protocol was approved by the Institutional Animal Care and Use Committee (Protocol 85-10-213).

Rat serum $\mathrm{T}_{4}$ was measured with a Clinical Assays Kit (Travenol Laboratories, Inc.). Serum $T_{3}$ was determined with a $T_{3}$ RIABEAD Diagnostic Kit (Abbott Laboratories, North Chicago, IL). For the $T_{3}$ assay, nonradioactive $T_{3}$ standards were prepared in $T_{3}$-depleted rat serum and were substituted for the standards provided by the manufacturer. Rat serum was depleted of $T_{4}$ and $T_{3}$ by treatment with dextran-

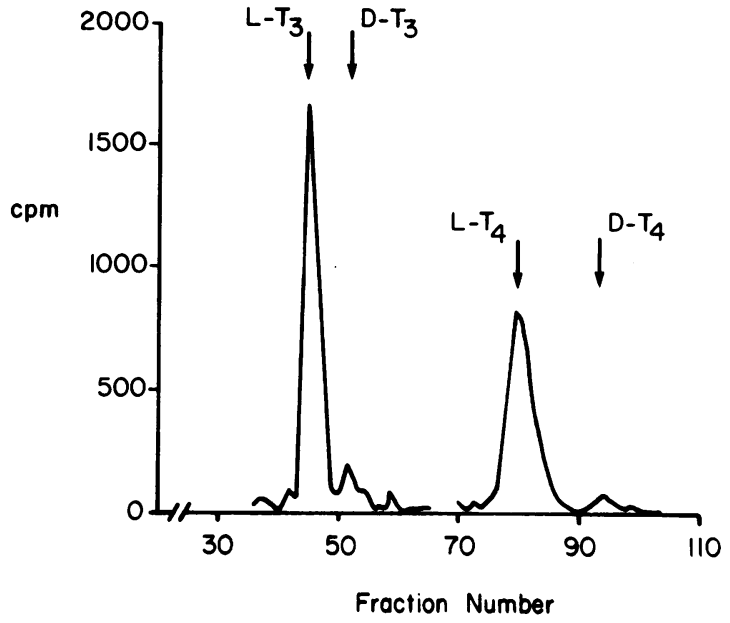

Figure 1. HPLC analysis of $\mathrm{L}-\left[{ }^{125} \mathrm{I}\right] \mathrm{T}_{3}$ and $\mathrm{L}-\left[{ }^{125} \mathrm{I}\right] \mathrm{T}_{4}$. Between 5,000$10,000 \mathrm{cpm}$ of $\mathrm{L}-\left[{ }^{125} \mathrm{I}\right] \mathrm{T}_{3}$ and $\mathrm{L}-\left[{ }^{125} \mathrm{I}\right] \mathrm{T}_{4}$ together with $2.5 \mathrm{ng}$ of $\mathrm{L}-\mathrm{T}_{3}$, $L-T_{4}, D-T_{3}$, and D-T $T_{4}$ were injected into the HPLC column. The flow rate was $1.5 \mathrm{ml} / \mathrm{min}$ and $0.3-\mathrm{ml}$ factions were collected.

coated charcoal as previously described (27). The RIA for $T_{4}$ has previously been validated for rat serum (27). GH was measured by RIA according to the methods provided by the National Hormone and Pituitary Program, National Institutes of Health. The intra- and inter-assay coefficients of variation for all assays was $<10 \%$.

Free $T_{4}$ and free $T_{3}$ fractions were determined in undiluted rat serum by an ultrafiltration method previously described (22). Free $T_{4}$ and free $T_{3}$ concentration in rat serum was then calculated as the product of the $T_{3}$ and $T_{4}$ concentrations and their respective free fractions.

Cell culture. Asynchronous monolayer cultures of GC cells were maintained in DME supplemented with 10\% normal serum (calf/ horse, 2:1; NS-DME) as previously described (28). Medium that was depleted of iodothyronines was prepared as follows: calf serum was treated with Dowex $1 \times 8,400$-mesh, anion exchange resin according to the procedure described by Samuels et al. (23). This treatment was shown to decrease serum $\mathrm{T}_{4}$ (Clinical Assays Kit, Travenol Laboratories, Inc.) from 58.0 to $1.3 \mathrm{nM}$ and serum $\mathrm{T}_{3}$ from 3.0 to $<0.05 \mathrm{nM}$ (29). DME containing 10\% resin-treated serum alone (RT-DME) or RT-DME that was supplemented with $T_{3}$ and $T_{4}$ were employed in various experiments as described below. The free $T_{3}$ and free $T_{4}$ fractions in RT-DME that was supplemented with various concentrations of $T_{3}$ and $T_{4}$ were also measured by the ultrafiltration method (22). The concentrations of free $T_{3}$ and free $T_{4}$ in RT-DME that was supplemented with $T_{3}$ and $T_{4}$ were calculated from the product of $T_{3}$ and $T_{4}$ concentrations in the medium and the respective free fraction for each iodothyronine.

Occupancy of $T_{3}$ receptors by iodothyronines. GC cells were incubated in 6-cm diam culture dishes with $10 \mathrm{ml}$ of RT-DME supplemented with $T_{4}, T_{3},\left[{ }^{125} I\right] T_{4}$, and $\left.{ }^{131} I\right] T_{3}$. We used a medium-exchange protocol (30) to minimize the cellular uptake of $T_{3}$ generated from $T_{4}\left[T_{3}\left(T_{4}\right)\right]$ that was released into the medium. In this protocol, the medium was exchanged every $10 \mathrm{~h}$ with $10 \mathrm{ml}$ per dish of fresh and identical medium that was devoid of $T_{3}\left(T_{4}\right)$, as previously described (30). We have shown that this procedure limits the contribution of $\mathrm{T}_{3}\left(\mathrm{~T}_{4}\right)$ to $<16 \%$ of the total medium $\mathrm{T}_{3}(30)$.

Initial studies were done to determine the time of equilibration between nuclear and medium iodothyronines. In subsequent studies, cells were harvested after $24 \mathrm{~h}$ of incubation, a time when equilibrium between medium iodothyronines and cellular pools had been attained (See Results). The nuclear fraction was prepared (30) and assayed for radioactivity in an Autogamma Spectrometer (Packard Instruments Co., Downers Grove, II). The counts per minute in the ${ }^{125}$ I channel was 
corrected for counts per minute of ${ }^{131} I$ that appeared in the ${ }^{125} I$ channel. Nuclear iodothyronines were then extracted by addition of $0.5 \mathrm{ml}$ of $85 \%$ ethanol for $16 \mathrm{~h}$ at $20^{\circ} \mathrm{C}$. $<5 \%$ of the ${ }^{125} \mathrm{I}$ or ${ }^{131} \mathrm{I}$ remained in the nuclear pellet after this procedure. Nuclear extracts were evaporated under a stream of $\mathrm{N}_{2}$, resuspended in $50-100 \mu \mathrm{l}$ of methanol/ $\mathrm{NH}_{3}$ (95:5, vol/vol). Samples were applied to Whatman 3 paper for descending chromatography in $t$-amyl alcohol $/ \mathrm{NH}_{3} / \mathrm{hexane}(5: 6: 1, \mathrm{vol} / \mathrm{vol} / \mathrm{vol})$ at $37^{\circ} \mathrm{C}$ as previously described (22). After chromatography, the paper was dried and the location of iodide, $T_{4}$, and $T_{3}$ was identified (22). The counts per minute corresponding to each component was then determined as described (22). Moles of $T_{3}\left(T_{4}\right)$ in individual nuclear samples was calculated from the product of the total counts per minute of ${ }^{125} \mathrm{I}$, the percentage of total counts per minute corresponding to $\left[{ }^{125} \mathrm{I}\right] \mathrm{T}_{3}$, determined by chromatography, and the specific activity of medium $T_{4}$ in each experiment. The result was then multiplied by 2 since only one half of the $T_{3}$ molecules generated from $\left[{ }^{125} \mathrm{I}\right] \mathrm{T}_{4}$ are radiolabeled (31). The moles of exchangeable $T_{3}\left[T_{3}\left(T_{3}\right)\right]$ and the moles of $T_{4}$ in a specific nuclear fraction were determined after paper chromatography as described above. The nonspecific binding of $T_{3}\left(T_{3}\right), T_{3}\left(T_{4}\right)$, and $T_{4}$ in the nuclear fraction was measured by incubating the cells with $3,000 \mathrm{nM}$ $T_{3}$. Nonspecific binding was always $<5 \%$ of the nuclear counts for $T_{3}\left(T_{3}\right), T_{3}\left(T_{4}\right)$, and $T_{4}$. Nonspecific conversion of $T_{4}$ to $T_{3}$ was measured by incubating medium without cells at $37^{\circ} \mathrm{C}$. Nonspecific conversion was $<0.05 \%$ of the counts added to the medium.

Interaction of $T_{3}$ and $T_{4}$ with $T_{3}$ nuclear receptors. $T_{3}$ nuclear receptor binding capacity was determined in each experiment. Dishes of $G C$ cells were incubated for $24 \mathrm{~h}$ with different $T_{3}$ and $T_{4}$ concentrations according to the medium exchange protocol (30). After $24 \mathrm{~h}$, cells were rinsed with serum-free medium and then incubated for $3 \mathrm{~h}$ with $5 \mathrm{nM}$ $\left[{ }^{125} \mathrm{I}\right] \mathrm{T}_{3}$ at $37^{\circ} \mathrm{C}$. Under these conditions, $>90 \%$ of $\mathrm{T}_{3}$ receptors are occupied with $\mathrm{T}_{3}$. Cells were then harvested, and nuclei were isolated and assayed for radioactivity. Nonspecific binding was always $<5 \%$ of total binding.

$T R$ affinity for $T_{3}$ and $T_{4}$ in GC cells nuclear extracts. Nuclear extracts were prepared as previously described (26). $200 \mu \mathrm{l}$ of nuclear extract supplemented with $10 \mathrm{pM}\left[{ }^{125} \mathrm{I}\right] \mathrm{T}_{3}$ and $0-5 \mathrm{nM}$ nonradioactive $\mathrm{T}_{3}$ or $0.2-500 \mathrm{nM}$ nonradioactive $\mathrm{T}_{4}$ in a total volume of $0.5 \mathrm{ml}$ of 20 $\mathrm{mM}$ Tris/ $\mathrm{HCl}, \mathrm{pH} 7.8,0.4 \mathrm{M} \mathrm{NaCl}$, and $5 \mathrm{mM}$ dithiothreitol were incubated for $72 \mathrm{~h}$ at $0^{\circ} \mathrm{C}$. Nonspecific binding, $<10 \%$ of total binding, was determined as previously described (32). At the end of incubation, receptor-bound $\left[{ }^{125} \mathrm{I}\right] \mathrm{T}_{3}$ was separated from free $\left[{ }^{125} \mathrm{I}\right] \mathrm{T}_{3}$ with Dowex $1 \times 8,400$-mesh anion exchange resin as described (32). $K_{\mathrm{a}}$ of $\mathrm{T}_{3}$ was calculated by Scatchard analysis. $K_{\mathrm{a}}$ of $\mathrm{T}_{\mathbf{4}}$ was calculated as the product of the molar ratio: $\left[\mathrm{T}_{3}\right] /\left[\mathrm{T}_{4}\right]$ that was observed to cause $50 \%$ displacement of $\left.{ }^{125} \mathrm{I}\right] \mathrm{T}_{3}$ from TR (R), and the $K_{\mathrm{a}}$ of $\mathrm{T}_{3}$. Thus, $K_{\mathrm{a}} \mathrm{T}_{4}=K_{\mathrm{a}} \mathrm{T}_{3} \cdot \mathrm{R}$.

$T R$ affinity for $T_{3}$ and $T_{4}$ in intact $G C$ cells. GC cells were plated in NS-DME. At the beginning of each experiment, they were rinsed with serum-free medium and incubated for $4 \mathrm{~h}$ at $37^{\circ} \mathrm{C}$ with serum-free medium supplemented with $13 \mathrm{pM}\left[{ }^{125} \mathrm{I}\right] \mathrm{T}_{3}, 10 \mu \mathrm{M}$ iopanoic acid, and 0-3 nM nonradioactive $T_{3}$ or $0-50 \mathrm{nM}$ nonradioactive $T_{4}$. Cells were then harvested as described previously (33). Nuclear $\left[{ }^{125} \mathrm{I}\right] \mathrm{T}_{3}$ and nonspecific binding were determined as previously described (33). The relative affinity of TR for $T_{3}$ and $T_{4}$ was assessed from the molar ratio $\left[\mathrm{T}_{3}\right] /\left[\mathrm{T}_{4}\right]$ that was observed to cause $50 \%$ displacement of $\left[{ }^{125} \mathrm{I}\right] \mathrm{T}_{3}$ from TR during these incubations.

Data were expressed as mean \pm SEM. Statistical analyses were by Student's $t$ test or analysis of variance when appropriate (34).

\section{Results}

Medium free $T_{4}$ and $T_{3}$ concentrations. Since GC cells were originally cloned from a rat GH-producing pituitary tumor, the relative roles of $T_{3}$ and $T_{4}$ in TR occupancy for the euthyroid state should be determined in incubations with physiological free $T_{3}$ and free $T_{4}$ concentrations. Initial studies were, there-
Table I. Total and Free $T_{3}$ and $T_{4}$ Concentrations in Rat Serum

\begin{tabular}{cccc}
\hline & $\begin{array}{c}\text { Total } \\
\text { concentration }\end{array}$ & $\begin{array}{c}\text { Free } \\
\text { fraction }\end{array}$ & $\begin{array}{c}\text { Free } \\
\text { concentration }\end{array}$ \\
\hline & $n M$ & $\%$ & $p M$ \\
$\mathrm{~T}_{3}$ & $1.07 \pm 0.07$ & $0.83 \pm 0.04$ & $8.8 \pm 0.7$ \\
$\mathrm{~T}_{4}$ & $60.9 \pm 2.8$ & $0.026 \pm 0.001$ & $15.4 \pm 0.6$
\end{tabular}

Serum was collected from normal rats. Serum $T_{3}$ and $T_{4}$ were measured by radioimmunoassay and the free hormone fractions were measured by ultrafiltration of undiluted serum. Entries are mean \pm SE $(n=9)$.

fore, designed to measure the free $T_{3}$ and free $T_{4}$ concentration of rat serum so that these concentrations could be duplicated in tissue culture medium (Table I). The intensity of rat serum protein binding of $T_{4}$ and $T_{3}$, was determined by ultrafiltration of undiluted serum. The bound/free ratio was 3,845 for $T_{4}$ and 120 for $T_{3}$. Thus, the intensity of $T_{4}$ binding by rat serum proteins was 32-fold greater than that of $T_{3}$. Mean rat serum free $T_{3}$ and free $T_{4}$ concentration were 8.8 \pm 2.2 and 15.4 \pm 1.7 pM, respectively $(P<0.001)$.

The concentration of $T_{3}$ and $T_{4}$ in RT-DME that would result in free $T_{3}$ and free $T_{4}$ concentrations similar to physiological free $T_{3}$ and free $T_{4}$ concentrations of rat serum was determined by measuring free $T_{3}$ and free $T_{4}$ in RT-DME that was enriched with increasing concentrations of $T_{3}$ and $T_{4}$ (Fig. 2). In this experiment, supplementation of RT-DME with $110 \mathrm{pM}$ $T_{3}$ and $1.4 \mathrm{nM} \mathrm{T}_{4}$ resulted in medium free $T_{3}\left(\mathrm{MFT}_{3}\right)$ and medium free $\mathrm{T}_{4}\left(\mathrm{MFT}_{4}\right)$ concentrations that were the same as the respective free hormone concentrations in rat serum. During these studies, we noted some variability in the concentration of medium $T_{3}$ and $T_{4}$ that were necessary to establish physiological conditions. Further experiments revealed that treatment of calf serum with resin to deplete serum of thyroid hormones resulted in a variable decrease in binding of $T_{4}$ and $\mathrm{T}_{3}$ (Table II). Because of this variability, unless otherwise indicated, experimental media used in these studies were studied as in Fig. 2 in order to be certain that $\mathrm{MFT}_{3}$ and $\mathrm{MFT}_{4}$ were similar to those in rat serum.

Occupancy of nuclear receptors by $T_{4}$. Initial studies were done to determine the time at which equilibrium had occurred between nuclear and medium iodothyronines in incubations of GC cells employing the medium exchange protocol (Table III). Receptor occupancy by $T_{3}\left(T_{3}\right), T_{3}\left(T_{4}\right)$, and $T_{4}$ achieved after $22 \mathrm{~h}$ of incubation was equivalent to that achieved after $28 \mathrm{~h}$ of incubation. These findings suggested that medium iodothyronines were equilibrated with nuclear iodothyronines after $22 \mathrm{~h}$ of incubation. All subsequent studies were therefore carried out after $24 \mathrm{~h}$ of incubation.

The occupancy of nuclear TR by $\mathrm{T}_{\mathbf{4}}$ was studied in GC cells cultured with near-physiological $\mathrm{MFT}_{3}$, achieved by supplementing RT-DME with $85 \mathrm{pM} \mathrm{T}_{3}$, and with different concentrations of medium $T_{4}, 0.5-5.0 \mathrm{nM}$. These medium $\mathrm{T}_{4}$ concentrations were selected because they were both below and above $1.4 \mathrm{nM}$, the concentration that results in physiological free $T_{4}$, (15.4 pM). As seen in Fig. 3, which depicts a representative experiment, incubation with increasing medium $T_{4}$ concentrations resulted in a progressive and significant increase in TR 


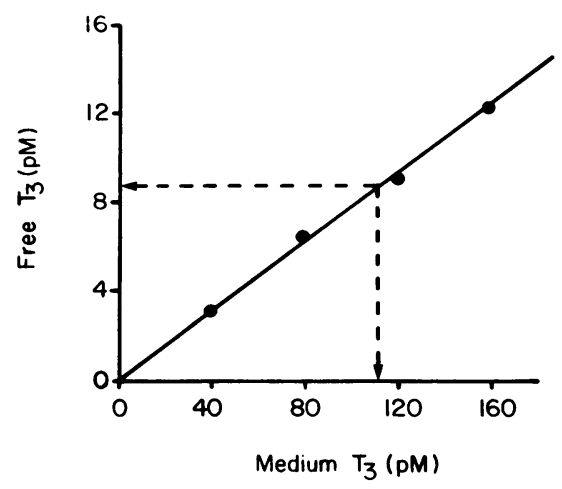

occupancy by both $T_{4}$ and $T_{3}\left(T_{4}\right)$ as well a decrease in TR occupancy by $\mathrm{T}_{3}\left(\mathrm{~T}_{3}\right)$. These iodothyronines together occupied $28.8 \pm 0.1 \%$ of TR binding sites when GC cells were incubated with $0.5 \mathrm{nM} \mathrm{T}_{4}$. TR occupancy by all iodothyronines increased progressively with increasing medium $T_{4}$ to $41.0 \pm 1.0 \%$ occupancy when GC cells were incubated with $5.0 \mathrm{nM} \mathrm{T}_{4}$. At physiological $\mathrm{MFT}_{4}, 15.4 \mathrm{pM}, \mathrm{T}_{4}$ accounted for $7.5 \%, \mathrm{~T}_{3}\left(\mathrm{~T}_{4}\right)$ for $32.5 \%$, and $\mathrm{T}_{3}\left(\mathrm{~T}_{3}\right)$ for $60.0 \%$ of the occupied $\mathrm{TR}$ binding sites. After incubation with $5.0 \mathrm{nM} \mathrm{T}$, which was assumed to increase $\mathrm{MFT}_{4}$ 3.6-fold, $\mathrm{T}_{4}$ accounted for $20.4 \%, \mathrm{~T}_{3}\left(\mathrm{~T}_{4}\right)$ for $40.3 \%$, and $T_{3}\left(T_{3}\right)$ for $39.3 \%$ of the occupied TR binding sites. Thus, $T_{4}$ and $T_{3}$ derived from $T_{4}$ constituted the major portion of iodothyronine bound to TR in GC cells cultured with raised concentrations of $\mathrm{MFT}_{4}$.

Estimation of nuclear free iodothyronine concentration. The magnitude of the contribution of $\mathrm{T}_{4}$ to TR occupancy, illustrated in Fig. 3, was unanticipated since we had assumed that the $T_{3}$ and $T_{4}$ concentrations in nucleus would change in proportion to the $\mathrm{MFT}_{3}$ and $\mathrm{MFT}_{4}$ concentrations. This is because our studies (see below) suggested that the affinity of TR for $\mathrm{T}_{4}$ was $<3 \%$ of the affinity of $\mathrm{T}_{3}$. Since $\mathrm{FT}_{3}$ concentration in the nucleus $\left(\mathrm{NFT}_{3}\right)$ has been reported to be greater than that in plasma (35), the present findings might be explained by nuclear free $\mathrm{T}_{4}\left(\mathrm{NFT}_{4}\right)$ concentrations that were disproportionately greater than those of $\mathrm{NFT}_{3}$. This hypothesis was tested by calculating the nuclear free iodothyronine concentration $[\mathrm{H}]$ from the law of mass action (35): $K_{\mathrm{a}}=\left[\mathrm{TR}_{\mathrm{O}}\right] /\left([\mathrm{H}]\left[\mathrm{TR}_{\mathrm{u}}\right]\right)$.

The concentration of occupied TR, [TR 0 , and unoccupied

Table II. Effect of Resin Treatment of Calf Serum on the Free Fraction of $T_{3}$ and $T_{4}$

\begin{tabular}{cccc}
\hline & \multicolumn{2}{c}{ Free hormone fraction } & \\
\cline { 2 - 3 } & Control & Resin treatment & $P$ \\
\hline$\%$ & $\%$ & \\
$\mathrm{~T}_{3}$ & $0.455 \pm 0.094$ & $0.841 \pm 0.126$ & $<0.025$ \\
$\mathrm{~T}_{4}$ & 0.043 & 0.100 &
\end{tabular}

Resin-treated calf serum was prepared as in Methods. $T_{3}$ and $T_{4}$ were added to resin-treated calf serum to restore the concentrations that were present before treatment with resin. Entries for $T_{3}$ are mean $\pm S E$ $(n=3)$. Entries for $T_{4}$ are the average of duplicate measurements which varied $<5 \%$ from the average value.
$T R,\left[T R_{u}\right]$, can readily be determined experimentally as in Fig. 3. $K_{\mathrm{a}}$ for $\mathrm{T}_{3}, K_{\mathrm{a}} \mathrm{T}_{3}$, was determined by Scatchard analysis in nuclear extracts of GC cells (Fig. 4). In three experiments, $K_{\mathrm{a}} \mathrm{T}_{3}$ was $6.3 \times 10^{9}, 8.6 \times 10^{9}$, and $6.1 \times 10^{9} \mathrm{liters} / \mathrm{mol}$; mean $K_{\mathrm{a}} \mathrm{T}_{3}$ was $7.0 \pm 1.4 \times 10^{9}$ liters $/ \mathrm{mol}$.

Three experiments to determine nuclear occupancy by $T_{4}$ and $T_{3}\left(T_{3}\right)$ were carried out in GC cells incubated at physiological $\mathrm{MFT}_{3}$ and $\mathrm{MFT}_{4}$ and the results were used to calculate $\mathrm{NFT}_{3}$ (Table IV). Mean $\mathrm{NFT}_{3}$ varied between $29.4 \pm 0.2$ and $50.0 \pm 3.1 \mathrm{pM}$ in the three experiments, and the nuclear $/ \mathrm{me}-$ dium ratio $(\mathrm{N} / \mathrm{M})$ for free $\mathrm{T}_{3}$ varied between $3.4 \pm 0.3$ and $5.9 \pm 0.4$. These findings indicate that free $T_{3}$ is concentrated in the nucleus in comparison to the medium and are concordant with data reported for rat liver, kidney, brain, and heart (35).

The relative displacement of $\left[{ }^{125} \mathrm{I}\right] \mathrm{T}_{3}$ by $\mathrm{T}_{3}$ and $\mathrm{T}_{4}$ in the nuclear extracts of GC cells is illustrated in Fig. 5. For three experiments, the concentration of $\mathrm{T}_{4}$ required for $50 \%$ displacement of $\left[{ }^{125} \mathrm{I}\right] \mathrm{T}_{3}$ was 42-, 40-, and 44-fold greater than the concentration of $\mathrm{T}_{3}$ required for $50 \%$ displacement of $\left[{ }^{125} \mathrm{I}\right] \mathrm{T}_{3}$. Thus, mean $\mathrm{R}=1 / 42 \pm 1.2=0.024 \pm 0.006$ and $K_{\mathrm{a}} \mathrm{T}_{4}=K_{\mathrm{a}} \mathrm{T}_{3}$. $R=0.17 \pm 0.04 \times 10^{9}$ liters $/ \mathrm{mol}$.

The $\mathrm{NFT}_{4}$ concentration was calculated using the calculated $K_{\mathrm{a}} \mathrm{T}_{4}$ and the TR occupancy data from three experiments carried out at physiological $\mathrm{MFT}_{4}$ and $\mathrm{MFT}_{3}$ concentration

Table III. Equilibration of Nuclear and Medium Thyroid Hormones

\begin{tabular}{ccccc}
\hline & \multicolumn{4}{c}{$\mathrm{T}_{3}$ nuclear receptors } \\
\cline { 2 - 5 } $\begin{array}{c}\text { Duration of } \\
\text { incubation }\end{array}$ & Total & \multicolumn{3}{c}{ Occupancy } \\
\cline { 2 - 5 } & $\mathrm{T}_{4}$ & $\mathrm{~T}_{3}\left(\mathrm{~T}_{4}\right)$ & $\mathrm{T}_{3}\left(\mathrm{~T}_{3}\right)$ \\
\hline$h$ & $f$ fmol/dish & $\%$ & $\%$ & $\%$ \\
22 & $356.3 \pm 17.0$ & $8.1 \pm 0.7$ & $11.6 \pm 0.6$ & $5.9 \pm 0.3$ \\
28 & $372.7 \pm 14.4^{*}$ & $8.4 \pm 0.3^{*}$ & $12.7 \pm 0.3^{*}$ & $6.2 \pm 0.3^{*}$ \\
\hline
\end{tabular}

GC cells were plated in NS-DMEM. After $3 \mathrm{~d}$ they were rinsed with RT-DME and then incubated with RT-DME supplemented with 40 $\mathrm{pM} \mathrm{T}_{3}$ and $2.5 \mathrm{nM} \mathrm{T}_{4}$. The medium exchange protocol described in Methods was used to minimize the cellular reuptake of $T_{3}\left(T_{4}\right)$. Nuclear TR occupancy was determined after 22 and $28 \mathrm{~h}$ as per Methods. Each value represents the mean \pm SE for three determinations.

* Not significantly different, $P>0.05$. 


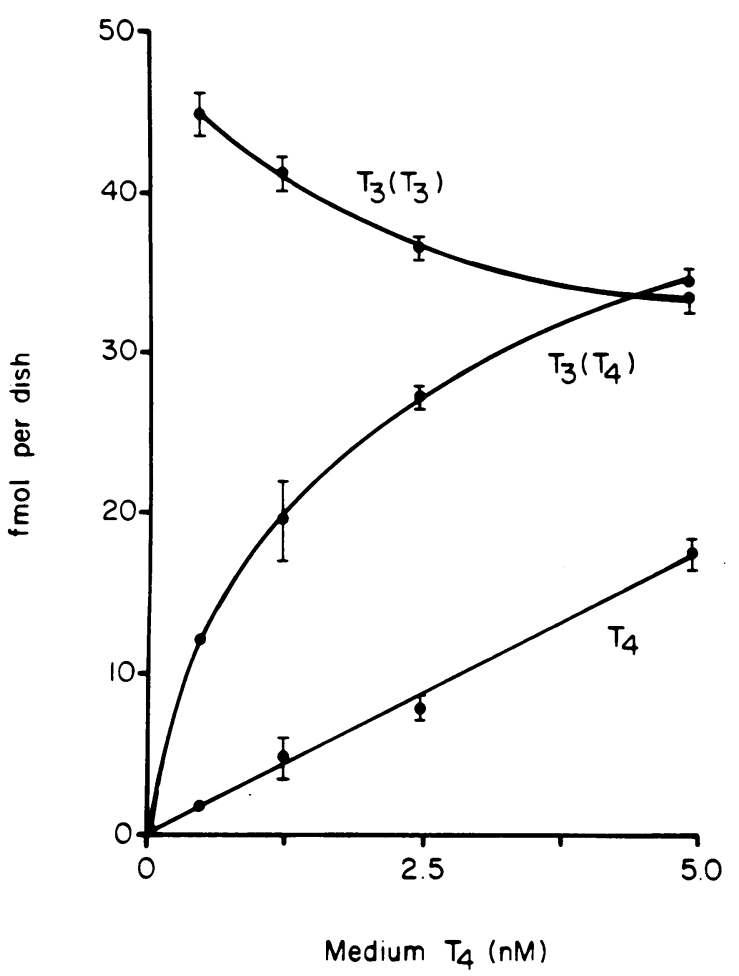

Figure 3. Effect of increasing medium $T_{4}$ on $T_{3}$ nuclear receptor occupancy. GC cells were plated in NS-DME for $48 \mathrm{~h}$. Cells were rinsed briefly with RT-DME and then cultured in RT-DME supplemented with $85 \mathrm{pM} \mathrm{T}_{3}$ and increasing concentrations of $\mathrm{T}_{4}(0.5-5.0 \mathrm{nM})$. The medium exchange procedure (see Methods) was employed for $24 \mathrm{~h}$ to minimize accumulation and cellular reuptake of $T_{3}\left(T_{4}\right)$. Cells were then harvested and nuclear TR occupancy determined as described in Methods. Entries are mean $\pm \mathrm{SE}(n=3)$.

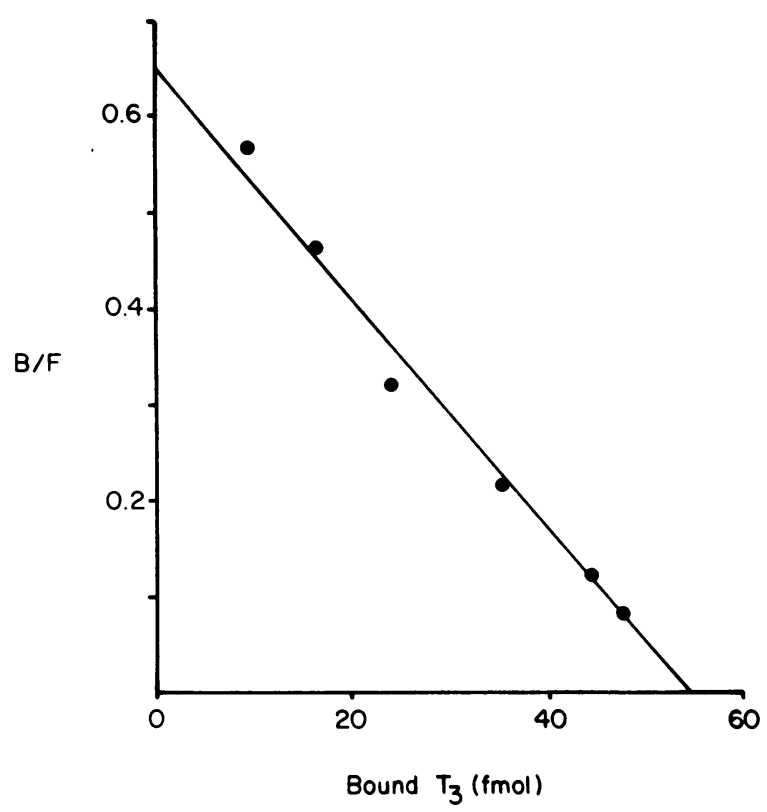

Figure 4. Scatchard analysis of $T_{3}$ binding to $T_{3}$ receptors in nuclear extracts. GC cells were cultured with NS-DME for $48 \mathrm{~h}$. Cells were harvested and nuclear extracts prepared as described in Methods. Each point is the average of two measurements which differed $<10 \%$.
(Table IV). Mean NFT 4 was 12.4 $\pm 0.7-, 19.3 \pm 2.3-$, and $6.5 \pm 0.3$-fold greater than $\mathrm{MFT}_{4}$ concentration in three experiments. Moreover, mean $\mathrm{NFT}_{4}$ concentration significantly exceeded mean $\mathrm{NFT}_{3}$ concentration in all studies. Further analysis of the $N / M$ ratios of free $T_{4}$ and free $T_{3}$ revealed that mean $\mathrm{N} / \mathrm{M}$ free $\mathrm{T}_{4}$ was $2.7 \pm 0.1-, 3.3 \pm 0.2-$, and $1.9 \pm 0.1$-fold greater than $N / M$ free $T_{3}$ in the three experiments. These findings suggest that, relative to medium free iodothyronine concentration, free $T_{4}$ is concentrated in the nucleus to an $\sim 2$.6-fold greater extent than free $T_{3}$ during incubations at physiological $\mathrm{MFT}_{3}$ and $\mathrm{MFT}_{4}$.

Since free $T_{4}$ is concentrated in the nucleus to a greater extent than free $T_{3}$, as suggested from our studies employing nuclear extracts, the concentration of $\mathrm{T}_{4}$ in medium relative to $T_{3}$ that would be necessary to displace $T_{3}$ from nuclear $T R$ in intact cells should be significantly smaller than that observed in nuclear extracts $\left(T_{4} 42.0 \pm 1.2\right.$-fold $\left.>T_{3}\right)$. The displacement of

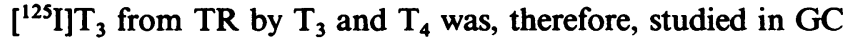
cells which were incubated with $10 \mu \mathrm{M}$ iopanoic acid to inhibit $T_{3}$ production from $T_{4}$. Preliminary experiments showed that incubation with $10 \mu \mathrm{M}$ iopanoic acid decreased nuclear $\mathrm{T}_{3}\left(\mathrm{~T}_{4}\right)$ to less than $3 \%$ of that found in control cultures incubated in the absence of iopanoic acid. The maximal amount of $\mathrm{T}_{3}$ generated from $\mathrm{T}_{4}$ under these experimental conditions was insufficient to displace $\left[{ }^{125} \mathrm{I}\right] \mathrm{T}_{3}$ from TR. Secondly, studies using nuclear extracts revealed that iopanoic acid did not influence the interaction of either $T_{3}$ or $T_{4}$ with TR. Lastly, studies with intact GC cells showed that iopanoic acid did not alter the concentration of $T_{3}\left(T_{3}\right)$ or $T_{4}$ in the nucleus.

A representative study of $T_{4}$ and $T_{3}$ interaction with $T R$ in intact cells, shown in Fig. 6, indicates that the concentration of $\mathrm{T}_{4}$ required for $50 \%$ displacement of $\left[{ }^{125} \mathrm{I}\right] \mathrm{T}_{3}$ from nuclear TR was 8.3-fold greater than the concentration of $T_{3}$ required for $50 \%$ displacement of $\left[{ }^{125} \mathrm{I}\right] \mathrm{T}_{3}$. The mean value was $9.1 \pm 1.5-$ fold $(n=3)$, significantly smaller than observed in studies employing nuclear extracts, $42.0 \pm 1.2$-fold $(P<0.001)$.

Relationship between medium $T_{4}$ and $N F T_{4}$. We used data from the experiment shown in Fig. 3 and the apparent equilibrium association constant for $T_{3}$ and $T_{4}$, listed above, to determine whether changes in medium $T_{4}$ concentration would be reflected by comparable changes in $\mathrm{NFT}_{4}$ (Table V). GC cells were incubated with $0.085 \mathrm{nM} \mathrm{T}_{3}$, which resulted in near-physiological $\mathrm{MFT}_{3} . \mathrm{NFT}_{3}$ was about five-fold greater than $\mathrm{MFT}_{3}$ and was not influenced by increasing medium $T_{4}$, over a wide range. Increasing medium $\mathrm{T}_{4}$ from 0.5 to $5.0 \mathrm{nM}$ resulted in parallel changes in $\mathrm{NFT}_{4}$. $\mathrm{NFT}_{4}$ always exceeded $\mathrm{NFT}_{3}$. At physiological $\mathrm{MFT}_{4}$, observed in incubations with $1.25 \mathrm{nM} \mathrm{T}_{4}$, $\mathrm{NFT}_{4}$ was 4.9-fold greater than $\mathrm{NFT}_{3}$.

$T_{4}$ occupancy of nuclear $T R$ when medium $T_{3}$ is decreased. Two experiments were carried out to determine the occupancy of $T R$ by $T_{4}$ and $T_{3}\left(T_{4}\right)$ when medium $T_{3}$ was decreased, an experimental protocol that has relevance to sick patients with decreased serum free $T_{3}$ (Table VI). The total number of TR was not influenced by changes in medium $T_{4}$ and $T_{3}$ in these experiments. However, a decrease in medium $\mathrm{T}_{3}$ from physiological levels, $0.11 \mathrm{nM}$, to $0.03 \mathrm{nM}$ resulted in a significant decrease in abundance of total occupied TR (Table VI, B). TR occupied by $T_{3}\left(T_{3}\right)$ decreased and $T R$ occupied by $T_{3}\left(T_{4}\right)$ increased significantly even in the absence of changes of medium $T_{4}$. When medium $T_{4}$ was increased from 1.4 to $2.8 \mathrm{nM}$, in the continuing presence of decreased medium $T_{3}$, TR total occu- 
Table IV. Relationship between Nuclear and Medium Free Iodothyronine Concentrations after Incubation of GC Cells with Physiological MFT, and $M_{4} T_{3}$

\begin{tabular}{|c|c|c|c|c|c|}
\hline \multirow{2}{*}{$\begin{array}{l}\text { Experiment } \\
\text { number }\end{array}$} & \multicolumn{2}{|c|}{ Nuclear free iodothyronine } & \multicolumn{2}{|c|}{$\begin{array}{l}\text { Nuclear/medium (N/M) free } \\
\text { iodothyronine ratios }\end{array}$} & \multirow{2}{*}{$\begin{array}{l}\text { Free } T_{4} N / M \\
\text { Free } T_{3} N / M\end{array}$} \\
\hline & $T_{4}$ & $T_{3}$ & $T_{4}$ & $\mathbf{T}_{3}$ & \\
\hline & $p M$ & $p M$ & & & \\
\hline \multirow[t]{5}{*}{1} & 185 & 41.1 & 13.7 & 4.8 & 2.9 \\
\hline & 164 & 39.6 & 12.1 & 4.7 & 2.6 \\
\hline & 153 & 36.9 & 11.3 & 4.3 & 2.6 \\
\hline & $167 \pm 9.4$ & $39.2 \pm 1.2$ & $12.4 \pm 0.7$ & $4.6 \pm 0.2$ & $2.7 \pm 0.1$ \\
\hline & $P<$ & 0.001 & & & \\
\hline \multirow[t]{5}{*}{2} & 232 & 43.9 & 15.0 & 5.2 & 2.9 \\
\hline & 313 & 53.7 & 20.2 & 6.3 & 3.2 \\
\hline & 353 & 52.5 & 22.8 & 6.2 & 3.7 \\
\hline & $299 \pm 35.6$ & $50.0 \pm 3.1$ & $19.3 \pm 2.3$ & $5.9 \pm 0.4$ & $3.3 \pm 0.2$ \\
\hline & $P<$ & 0.005 & & & \\
\hline \multirow[t]{5}{*}{3} & 109 & 29.2 & 7.0 & 3.4 & 2.1 \\
\hline & 95 & 29.2 & 6.1 & 3.4 & 1.8 \\
\hline & 97 & 29.7 & 6.3 & 3.5 & 1.8 \\
\hline & $100 \pm 4.4$ & $29.4 \pm 0.2$ & $6.5 \pm 0.3$ & $3.4 \pm 0.3$ & $1.9 \pm 0.1$ \\
\hline & $P<$ & 0.001 & & & \\
\hline
\end{tabular}

Nuclear free iodothyronine concentrations were calculated as described in Results using the mass action equation. Medium free iodothyronine concentration was determined from the product of the iodothyronine concentration and the free iodothyronine fraction which was measured by ultrafiltration. Entries are mean $\pm \operatorname{SE}(n=3)$.

pancy was restored to or near control values (Table VI, C). TR receptor occupancy was restored by a significant increase in occupancy by both $\mathrm{T}_{4}$ and $\mathrm{T}_{3}\left(\mathrm{~T}_{4}\right)$.

The decrease in TR total occupancy observed when medium $T_{3}$ was decreased (Table VI, B) and the restoration of TR occupancy to or near control values when medium $T_{4}$ was increased (Table VI, C) were paralleled by significant changes in $\mathrm{GH}$ production.

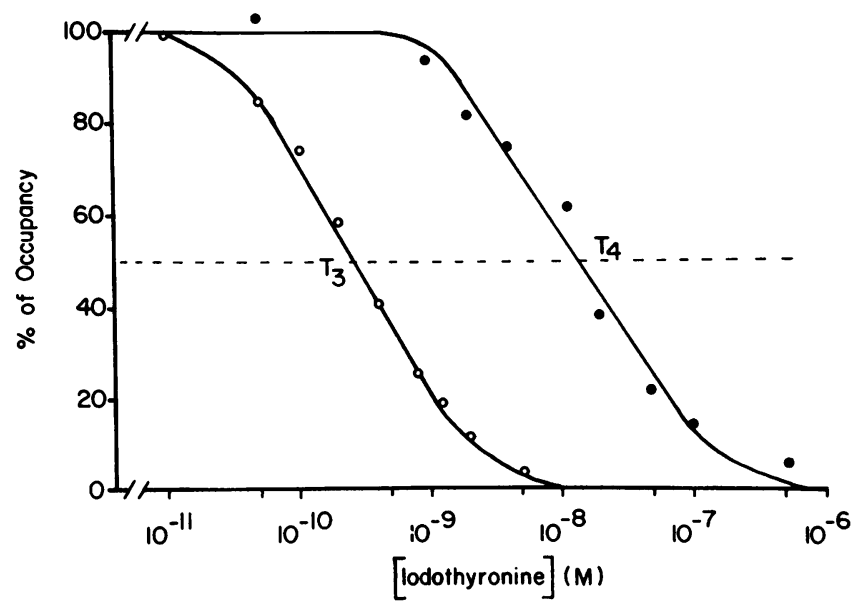

Figure 5. Relative displacement of $\left[{ }^{125} \mathrm{I}\right] \mathrm{T}_{3}$ from nuclear thyroid receptors in nuclear extracts. Nuclear extracts were prepared as described in legend to Fig. 4. Each point is the average of two determinations which differed $<10 \%$.

\section{Discussion}

Since GC cells were derived from a rat pituitary tumor, the premise of this investigation was that information potentially relevant to the intact euthyroid rat would most likely be ob-

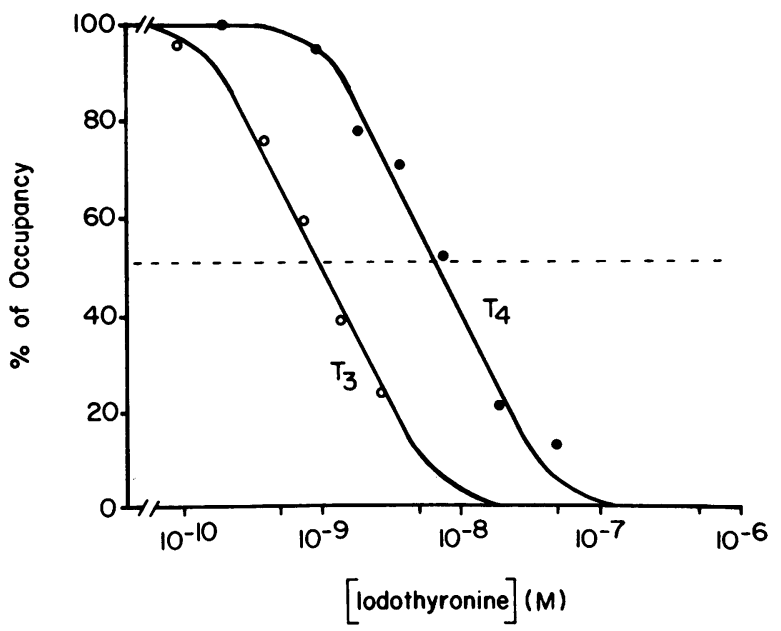

Figure 6. Relative displacement of $\left[{ }^{125} \mathrm{I}\right] \mathrm{T}_{3}$ from nuclear receptors during incubation of $G C$ cells with different concentrations of $T_{3}$ and $T_{4} . G C$ cells were plated in NS-DME for $72 \mathrm{~h}$. Cells were rinsed with serum free medium and then incubated with serum free medium supplemented with $13 \mathrm{pM}\left[{ }^{125} \mathrm{I}\right] \mathrm{T}_{3}, 10 \mu \mathrm{M}$ iopanoic acid and increasing concentrations of either $T_{3}$ or $T_{4}$. Cells were harvested after $4 \mathrm{~h}$ for determination of $\left.{ }^{125} \mathrm{I}\right] \mathrm{T}_{3}$ specifically bound to nuclei. Each point is the average of duplicate measurements which varied $<10 \%$. 
Table V. Relationship between Medium $T_{4}$ and Nuclear Free Iodothyronine Concentration

\begin{tabular}{lccccr}
\hline \multicolumn{2}{c}{ Medium } & & \multicolumn{2}{c}{ Nuclear free iodothyronine } & \\
$\mathrm{T}_{4}$ & $\mathrm{~T}_{3}$ & & $\mathrm{~T}_{4}$ & $\mathrm{~T}_{3}$ & \\
\hline$n M$ & $n M$ & & $p M$ & $p M$ & \\
& & & & & \\
0.5 & 0.085 & & $76.6 \pm 1.4$ & $44.2 \pm 0.2$ & 1.7 \\
1.25 & 0.085 & & $216.7 \pm 22.4$ & $44.3 \pm 1.8$ & 4.9 \\
2.5 & 0.085 & & $363.1 \pm 17.5$ & $41.5 \pm 0.8$ & 8.7 \\
5.0 & 0.085 & & $895.1 \pm 84.2$ & $42.0 \pm 3.4$ & 21.3
\end{tabular}

Nuclear free iodothyronine concentrations were calculated as described in Results using the mass action equation. Nuclear occupancy data were from the experiment depicted in Fig. 2. Entries are mean $\pm \operatorname{SE}(n=3)$.

tained when cells were exposed to medium free iodothyronine concentrations similar to those in euthyroid rat serum. Physiological medium free iodothyronine concentrations were achieved by supplementing RT-DME with between 90 and 115 $\mathrm{pM} \mathrm{T}_{3}$ and 1.2-1.4 $\mathrm{nM} \mathrm{T}$, concentrations that are significantly less than those reported previously to restore physiological concentrations (28). This difference results from the new finding that treatment of calf serum with Dowex $1 \times 8$ anion exchange resin to deplete endogenous iodothyronines increases the free fraction of both $T_{4}$ and $T_{3}$. The present experiments, however, do not define whether this increase in free fraction results from depletion of iodothyronine binding proteins or other constituents of serum that facilitate binding of iodothyronines.
After incubation of GC cells with physiological $\mathrm{MFT}_{4}$ and MFT $_{3}$ concentrations, $\mathrm{T}_{4}$ accounted for $5.4-10.0 \%$ of the occupied nuclear TR sites, a finding that is concordant with a previous reports concerning liver and kidney of euthyroid rats (15). Exposure of cells to increasing $\mathrm{MFT}_{4}$ in the presence of near physiological $\mathrm{MFT}_{3}$ concentration resulted in a progressive increase in the contribution of $\mathrm{T}_{4}$ and $\mathrm{T}_{3}\left(\mathrm{~T}_{4}\right)$ to nuclear $\mathrm{TR}$ occupancy and a modest decrease in occupancy by $T_{3}\left(T_{3}\right)$. When GC cells were maintained in $\mathrm{MFT}_{4}$ concentrations that were fourfold greater than the euthyroid value, $\mathrm{T}_{4}$ itself constituted $20 \%$ of the iodothyronine bound to TR. Lastly, incubation with increasing $\mathrm{MFT}_{4}$ was associated with an increase in total receptor occupancy from $20-30 \%$ in cells maintained at physiological $\mathrm{MFT}_{4}$ to $35-45 \%$ in cells cultured with fourfold increased concentrations of $\mathrm{MFT}_{4}$. Thus, in addition to an important role as a prohormone for $T_{3}\left(T_{4}\right)$ in GC cells, the present studies establish a role for $T_{4}$ itself in thyroid hormone action in GC cells cultured with physiologic concentrations of $\mathrm{MFT}_{4}$ and $\mathrm{MFT}_{3}$ and a much larger role when $\mathrm{MFT}_{4}$ is selectively increased.

A common clinical setting that is associated with altered serum free iodothyronine concentrations is the euthyroid patient with acute nonthyroidal disease. Such patients are often characterized by decreased concentrations of serum free $T_{3}$ and either unchanged or increased concentrations of serum free $T_{4}$ $(20-22,36)$. A role for the normal or raised serum free $T_{4}$ concentration in the maintenance of the euthyroid state in these patients has not been established. The present experiments suggest that $T_{4}$ may play an important role in the maintenance of normal TR occupancy and biologic activity when $\mathrm{MFT}_{3}$ is decreased. A decrease in $\mathrm{MFT}_{3}$ without changing $\mathrm{MFT}_{4}$ was associated with a proportional decrease in $\mathrm{T}_{3}\left(\mathrm{~T}_{3}\right)$ bound to nuclear TR, partially offset by a significant increase

Table VI. Effect of Changes in Medium $T_{4}$ and $T_{3}$ Concentrations on $T_{3}$ Nuclear Receptor Occupancy and GH Production

\begin{tabular}{|c|c|c|c|c|c|c|c|c|}
\hline \multirow{2}{*}{\multicolumn{2}{|c|}{$\begin{array}{c}\text { Medium } \\
\text { iodothyronine }\end{array}$}} & \multirow{3}{*}{$\begin{array}{l}\text { Incubation } \\
\text { condition }\end{array}$} & \multicolumn{5}{|c|}{$T_{3}$ nuclear receptors } & \multirow[b]{3}{*}{ Medium GH } \\
\hline & & & \multirow[b]{2}{*}{ Total } & \multicolumn{4}{|c|}{ Occupancy } & \\
\hline $\mathrm{T}_{3}$ & $\mathrm{~T}_{4}$ & & & $T_{4}$ & $T_{3}\left(T_{4}\right)$ & $\mathrm{T}_{3}\left(\mathrm{~T}_{3}\right)$ & Total & \\
\hline \multicolumn{2}{|c|}{$n M$} & & fmol/dish & $\%$ & $\%$ & $\%$ & $\%$ & $n g / d i s h$ \\
\hline 0.11 & 1.4 & $\mathbf{A}$ & $397.3 \pm 2.1$ & $1.3 \pm 0.1$ & $6.8 \pm 0.2$ & $15.7 \pm 0.1$ & $23.8 \pm 0.2$ & $5,371 \pm 100$ \\
\hline 0.03 & 1.4 & B & $390.6 \pm 7.1$ & $2.0 \pm 0.1$ & $10.2 \pm 0.2$ & $6.4 \pm 0.3$ & $18.7 \pm 0.7$ & $3,436 \pm 59$ \\
\hline \multirow[t]{4}{*}{0.03} & 2.8 & $\mathrm{C}$ & $395.7 \pm 43.9$ & $5.1 \pm 0.9$ & $12.4 \pm 1.1$ & $6.2 \pm 0.4$ & $23.7 \pm 2.41$ & $4,423 \pm 64$ \\
\hline & & A vs. $B$ & NS & NS & $<0.001$ & $<0.001$ & $<0.1>0.05$ & $<0.001$ \\
\hline & & A vs. $\mathrm{C}$ & NS & $<0.005$ & $<0.005$ & $<0.001$ & NS & $<0.001$ \\
\hline & & B vs. C & NS & $<0.005$ & $<0.025$ & NS & $<0.1>0.05$ & $<0.01$ \\
\hline 0.11 & 1.4 & A & $393.5 \pm 11.5$ & $3.4 \pm 0.3$ & $7.3 \pm 0.4$ & $23.1 \pm 0.9$ & $33.8 \pm 1.6$ & $4,790^{*}$ \\
\hline 0.03 & 1.4 & B & $380.3 \pm 7.4$ & $3.9 \pm 0.1$ & $11.2 \pm 0.3$ & $8.0 \pm 0.2$ & $23.1 \pm 0.3$ & $3,758 \pm 148$ \\
\hline \multirow[t]{4}{*}{0.03} & 2.8 & $\mathrm{C}$ & $377.0 \pm 8.1$ & $8.1 \pm 0.1$ & $12.1 \pm 0.2$ & $7.4 \pm 0.1$ & $27.7 \pm 0.3$ & $4,907 \pm 192$ \\
\hline & & A vs. $B$ & NS & $<0.05$ & $<0.001$ & $<0.001$ & $<0.001$ & $<0.01$ \\
\hline & & A vs. C & NS & $<0.001$ & $<0.001$ & $<0.001$ & $<0.005$ & NS \\
\hline & & B vs. C & NS & $<0.001$ & $P>0.1<0.05$ & NS & $<0.01$ & $<0.005$ \\
\hline
\end{tabular}

GC cells were plated in NS-DME for $24 \mathrm{~h}$. The cells were rinsed with serum-free medium and exposed to RT-DME supplemented with iodothyronine concentrations listed above. The medium-exchange procedure described in Methods was used to minimize the accumulation and cellular reuptake of $T_{3}\left(T_{4}\right)$. Nuclear TR occupancy was determined after $24 \mathrm{~h}$ as per Methods and, in separate dishes, medium was collected between 24 and $48 \mathrm{~h}$ for measurement of GH by RIA. Each value represents the mean \pm SE for three determinations. * Average of duplicate measurements that varied $<10 \%$. 
in TR-associated $T_{3}\left(T_{4}\right)$. Total nuclear TR occupancy by iodothyronines declined and this was paralleled by a decrease in GH production. The increase in $T_{3}\left(T_{4}\right)$ bound to $T R$ under these conditions could be due to development of cellular hypothyroidism which has been associated with increased activity of type II $\mathrm{T}_{4}-5^{\prime}$ deiodinase (37). Alternatively, the finding could be due to a decrease in product, $\left(\mathrm{T}_{3}\right)$, inhibition of the enzyme. Published reports suggest the former possibility is more likely since $T_{3}$ appears to have only minimal affect on enzyme activity (38).

When $\mathrm{MFT}_{4}$ concentration was increased to twofold the physiological value, nuclear TR occupancy and GH production were restored to or near the value observed when both $\mathrm{MFT}_{4}$ and $\mathrm{MFT}_{3}$ concentrations were similar to those in euthyroid rat serum. Both $T_{4}$ and a further increase in $T_{3}\left(T_{4}\right)$ contributed nearly equally to the restoration of nuclear TR occupancy under these conditions. These findings indicate that increased $\mathrm{MFT}_{4}$ concentrations significantly affected TR occupancy and biologic activity in GC cells that were incubated with decreased $\mathrm{MFT}_{3}$. A similar role may be postulated for the raised serum free $T_{4}$ concentration that occurs in many patients with nonthyroidal disease.

The significant contribution of $\mathrm{T}_{4}$ to nuclear TR occupancy in the present studies prompted a reexamination of TR interactions with $T_{4}$ and $T_{3}$. Studies of the relative concentrations of $T_{4}$ and $T_{3}$ that were required for $50 \%$ displacement of $T_{3}$ from TR sites in nuclear extracts of GC cells revealed that the avidity of TR for $\mathrm{T}_{4}$ was only $2.4 \%$ that of $\mathrm{T}_{3}$. In the present studies, the avidity of nuclear sites for $T_{4}, 2-4 \%$ that of $T_{3}$, was significantly less than reported for isolated rat liver nuclei, $8 \%$ that of $\mathrm{T}_{3}(39,40)$, nuclei from cultured $\mathrm{GH}_{1}$ cells, $10 \%$ that of $\mathrm{T}_{3}(39)$, or for extracts of rat liver nuclei or $\mathrm{GH}_{1}$ cell nuclei, $10 \%$ that of $\mathrm{T}_{3}(41)$. Nuclear TR receptors have recently been shown to be the cellular homologues of c-erb A proto-oncogenes (42) and several forms of TR that bind $T_{3}, \alpha 1, \beta 1$, and $\beta 2$, occur in different tissues. A number of these receptor forms from different tissues have been generated in vitro for studies of the binding of $T_{3}, T_{4}$, and iodothyronine analogues. A review of these data revealed a wide variation in the apparent avidity of TR for $T_{4}$ relative to $T_{3}$ that was not segregated to specific receptor forms. For $\alpha$ TR forms, the $T_{4}$ interaction relative to $T_{3}$ was $3.7 \%$ for TR from rat brain (43), $13.3 \%$ for TR from chicken embryonic tissue (44), $2.3 \%$ for TR from human kidney (45), and $11.5 \%$ for TR from rat liver (46). For $\beta$ TR forms, the TR interaction relative to $T_{3}$ was $17.9 \%$ for TR from human placenta (47) and 5\% for TR from rat liver (46). The wide variation in apparent avidity of different $T R$ forms for $T_{4}$ relative to $T_{3}$ suggests that significant differences in reaction conditions prevailed in these published reports. The $T_{3}$ content of $T_{4}$ solutions was not mentioned in any of these reports. In our view, variable $T_{3}$ contamination of $T_{4}$ solutions that were used to displace $T_{3}$ is a likely explanation for the differences between these studies. If the intrinsic avidity of $T R$ sites for $T_{4}$ is $2-3 \%$ that of $T_{3}$, as in the present report and in the report of Nakai et al. (45), 1-2\% contamination of $T_{4}$ solutions with $T_{3}$ would result in a significant increase in the apparent avidity of receptor for $T_{4}$. The magnitude of the affect of $T_{3}$ contamination would also be dependent of the degree of saturation of TR sites with radioactively labeled $T_{3}$.

Using the apparent association constants of TR for $T_{3}$ and $\mathrm{T}_{4}$, described herein, the calculated $\mathrm{NFT}_{3}$ was determined to be significantly greater than $\mathrm{MFT}_{3}$. This finding extends the observations of Oppenheimer and Schwartz (35) to cultured GC cells. The raised concentration of $\mathrm{NFT}_{3}$ relative to $\mathrm{MFT}_{3}$ (3-6fold) in cultured GC cells is appreciably smaller than reported for $\mathrm{NFT}_{3}$ in nuclei from rat liver, kidney, heart and brain (range: 50-250-fold) (35) but similar to the 7.6-fold gradient reported by Freake et al. (25) in cultured $\mathrm{GH}_{1}$ cells. The present studies also suggest that free $T_{4}$ is concentrated in $G C$ cell nuclei (6-20-fold greater than $\mathrm{MFT}_{4}$ ) and to a greater extent than $\mathrm{T}_{3}$. Relative to $\mathrm{MFT}_{4}$ and $\mathrm{MFT}_{3}$ concentration, $\mathrm{NFT}_{4}$ was concentrated to 1.9-3.3-fold greater extent than $\mathrm{NFT}_{3}$. The conclusion that $\mathrm{NFT}_{4}$ was concentrated in nuclei to a greater extent than $\mathrm{NFT}_{3}$ was strengthened by data obtained in intact $\mathrm{GC}$ cells maintained in $10 \mu \mathrm{M}$ iopanoic acid. The iopanoic acid decreased $\mathrm{T}_{3}$ production from $\mathrm{T}_{4}$ to $<3 \%$ of control values and neither influenced the avidity of TR for $T_{3}$ or $T_{4}$ nor the delivery of $\mathrm{T}_{4}$ into the cell. The results of these studies indicated that significantly smaller concentrations of $T_{4}$ relative to $T_{3}$ were required to displace $T_{3}$ from TR sites in intact cells than in nuclear extracts. A likely explanation for the difference is that free $T_{4}$ is concentrated to a greater extent than free $T_{3}$ in intact cells.

The present results do not provide new information concerning the cellular mechanisms responsible for maintaining the increased $\mathrm{NFT}_{4}$ and $\mathrm{NFT}_{3}$ gradients. Oppenheimer and Schwartz (35) reported that the principle gradient for free $T_{3}$ occurred between cytosol and nuclear compartments rather than between the plasma and cytosol compartments. They also suggested that the free $T_{3}$ gradient was probably maintained by an energy-dependent process (35). The finding that free $T_{4}$ gradients occur between nuclei and medium free $T_{4}$ in cultured GC cells and that the free $T_{4}$ gradients are larger than comparable gradients for free $T_{3}$ raise the possibility that separate transporters may exist for the two iodothyronines or that the affinity of a common transporter for $T_{4}$ is larger than for $T_{3}$.

\section{Acknowledgments}

The authors are indebted to Evette Gonzalez for preparing the manuscript. We appreciate the help of Victor B. Hatcher, Ph.D. in the HPLC studies.

These studies were supported by National Institutes of Health grants CA-16463-16 and CA-24604-12.

\section{References}

1. Taurog, A., and I. L. Chaikoff. 1948. The nature of the circulatory thyroid hormone. J. Biol. Chem. 176:639-656.

2. Gross, J., and R. Pitt-Rivers. 1952. The identification of 3:5:3'-tri-iodothyronine in human plasma. Lancet. i:439-443.

3. Maclagan, N. F., W. E. Sprott, and J. H. Wilkinson. 1952. Effect of 3:5:3'-Ltriiodothyronine and certain anti-thyroxine substances on the oxygen consumption of mice. Lancet. ii:915-916.

4. Wilkinson, J. H., and N. F. Maclagan. 1953. Effect of an anti-thyroxine compound on the metabolism of radioactive thyroxine and triiodothyronine in rats. Lancet. ii:1024-1025.

5. Lassiter, W. E., and J. B. Stanbury. 1958. The in vivo conversion of thyroxine to 3:5:3'-triiodothyronine. J. Clin. Endocrinol. Metab. 18:903-906.

6. Braverman, L. E., S. H. Ingbar, and K. Sterling. 1970. Conversion of thyroxine $\left(\mathrm{T}_{4}\right)$ to triiodothyronine $\left(\mathrm{T}_{3}\right)$ in athyreotic human subjects. $J$. Clin. Invest. 49:855-864.

7. Sterling, K., M. A. Brenner, and E.S. Newman. 1970. Conversion of thyroxine to triiodothyronine in normal human subjects. Science (Wash. DC). 169:1099-1103.

8. Surks, M. I., A. R. Schadlow, J. M. Stock, and J. H. Oppenheimer. 1973. Determination of iodothyronine absorption and conversion of $L$-thyroxine $\left(T_{4}\right)$ 
to $3,5,3^{\prime}$-triiodo-L-thyronine using turnover rate techniques. J. Clin. Invest. 52:805-811.

9. Kinlaw, W. B., H. L. Schwartz, and J. H. Oppenheimer. 1985. Decreased serum triiodothyronine in starving rats is due primarily to diminished thyroidal secretion of thyroxine. J. Clin. Invest. 75:1238-1241.

10. Oppenheimer, J. H., H. L. Schwartz, and M. I. Surks. 1972. Propylthiouracil (PTU) inhibits the conversion of $L$-thyroxine $\left(T_{4}\right)$ to $L$-triiodothyronine $\left(T_{3}\right)$ : a possible explanation of the anti- $\mathrm{T}_{4}$ effect of PTU and further support of the concept that $\mathrm{T}_{3}$ is the primary thyroid hormone. J. Clin. Invest. 51:2493-2497.

11. Oppenheimer, J. H., D. Koerner, M. I. Surks, and H. L. Schwartz. 1974. Limited binding capacity sites for L-triiodothyronine in rat liver nuclei: Nuclear cytoplasmic interrelation, binding constants, and crossreactivity with L-thyroxine. J. Clin. Invest. 53:768-777.

12. Samuels, H. H., and J. S. Tsai. 1973. Thyroid hormone action in cell culture: demonstration of nuclear receptors in intact cells and isolated nuclei. Proc. Natl. Acad. Sci. USA. 70:3488-3492.

13. van Doorn, J., D. van der Heide, and F. Roelfsema. 1983. Sources and quantity of 3,5,3'-triiodothyronine in several tissues of the rat. J. Clin. Invest. 72:1778-1992.

14. Crantz, F. R., J. E. Silva, and P. R. Larsen. 1982. An analysis of the sources and quantity of 3,5,3,'-triiodothyronine specifically bound to nuclear receptors in rat cerebral cortex and cerebellum. Endocrinology. 110:367-375.

15. Surks, M. I., and J. H. Oppenheimer. 1977. Concentration of L-thyroxine $\left(\mathrm{T}_{4}\right)$ and L-triiodothyronine $\left(\mathrm{T}_{3}\right)$ specifically bound to nuclear receptors in rat liver and kidney: quantitative evidence favoring a major role of $\mathrm{T}_{3}$ in thyroid hormone action. J. Clin. Invest. 60:555-562.

16. Silva, J. E., and P. R. Larsen. 1977. Pituitary nuclear 3,5,3'-triiodothyronine and thyrotropin secretion: an explanation for the effect of thyroxine. Science (Wash. DC). 198:617-620.

17. Silva, J. E., T. E. Dick, and P. R. Larsen. 1978. The contribution of local tissue thyroxine monodeiodination to the nuclear 3,5,3'-triiodothyronine in pituitary, liver, and kidney of euthyroid rats. Endocrinology. 103:1 196-1207.

18. Samuels, H. H., F. Stanley, and J. Casanova. 1979. Relationship of receptor affinity to the modulation of thyroid hormone nuclear receptor levels and growth hormone synthesis by L-triiodothyronine and iodothyronine analogues in cultured $\mathrm{GH}_{1}$ cells. J. Clin. Invest. 63:1229-1240.

19. Pascual, A., F. Montiel, and A. Aranda. 1987. Effects of iopanoic acid on thyroid hormone receptor, growth hormone production, and triiodothyronine generation from thyroxine in pituitary $\mathrm{GH}_{1}$ cells. Endocrinology. 120:10891096.

20. Oppenheimer, H. H., R. Squef, M. I. Surks, and H. Hauer. 1963. Binding of thyroxine by serum proteins evaluated by equilibrium dialysis and electrophoretic techniques: alterations in nonthyroidal disease. J. Clin. Invest. 41:17691782.

21. Bermudez, F., M. I. Surks, and J. H. Oppenheimer. 1975. High incidence of decreased serum triiodothyronine concentration in patients with nonthyroidal disease. J. Clin. Endocrinol. Metab. 41:27-40.

22. Surks, M. I., K. H. Hupart, C. Pan, and L. E. Shapiro. 1988. Normal free thyroxine in critical nonthyroidal illnesses measured by ultrafiltration of undiluted serum and equilibrium dialysis. J. Clin. Endocrinol. Metab. 67:1031-1039.

23. Samuels, H. H., F. Stanley, and J. Casanova. 1979. Depletion of L-3,5,3'triiodothyronine and L-thyroxine in euthyroid calf serum for use in cell culture studies of the action of thyroid hormone. Endocrinology. 105:80-85.

24. Kochupillai, N., and R. S. Yalow. 1978. Preparation, purification and stability of high specific activity ${ }^{125}$ I-labeled thyronines. Endocrinology. 102:128135.

25. Freake, H. C., A. D. Mooradian, H. L. Schwartz, and J. H. Oppenheimer. 1986. Stereospecific transport of triiodothyronine to cytoplasm and nucleus in $\mathrm{GH}_{1}$ cells. Mol. Cell. Endocrinol. 44:25-35.

26. Hay, I. D., T. M. Annesley, N. S. Jiang, and C. A. Gorman. 1981. Simultaneous determination of $D$ - and $L$-thyroxine in human serum by liquid chromatography with electrochemical detection. J. Chromatogr. 226:383-390.

27. Hupart, K. H., C. R. DeFesi, C. P. Katz, L. E. Shapiro, and M. I. Surks. 1990. Differential response to L-triiodothyronine of anterior pituitary GH
mRNA and $\beta$-TSH mRNA in a Walker 256 carcinoma-bearing rat model of non-thyroidal disease. Endocrinology. 126:616-621.

28. DeFesi, C. R., and M. I. Surks. 1981. 3,5,3'-triiodothyronine effects on the growth rate and cell cycle stages of cultured GC cells. Endocrinology. 108:259267.

29. Surks, M. I., A. R. Schadlow, and J. H. Oppenheimer. 1972. A new radioimmunoassay for plasma L-triiodothyronine: measurements in thyroid disease and in patients maintained on hormonal replacement. J. Clin. Invest. 51:3104-3113.

30. Halperin Y., L. E. Shapiro, and M. I. Surks. 1990. Medium 3,5,3'-triiodoL-thyronine $\left(\mathrm{T}_{3}\right)$ and $\mathrm{T}_{3}$ generated from L-thyroxine $\left(\mathrm{T}_{4}\right)$ are exchangeable in cultured GC cells. Endocrinology. 127:1050-1056.

31. Schwartz, H. L., M. I. Surks, and J. H. Oppenheimer. 1971. Quantitation of extrathyroidal conversion of L-thyroxine to 3,5,3'-triiodo-L-thyronine in the rat. J. Clin. Invest. 50:1124-1130.

32. Surks, M. I., I. J. Ramirez, L. E. Shapiro, and M. H. Kumarasiri. 1989. Effect of $\mathrm{Zn}$ (II) and other divalent cations on binding of 3,5,3'-triiodo-L-thyronine to nuclear receptors from cultured GC cells. J. Biol. Chem. 264:9820-9826.

33. Halperin, Y., L. E. Shapiro, and M. I. Surks. 1990. L-Triiodothyronine regulates cellular growth rate, growth hormone production, and down-regulation of nuclear $T_{3}$ receptors via distinct dose-response ranges in cultured GC cells. Endocrinology. 126:2321-2326.

34. Snedecor, G. W., and W. G. Cochran. 1967. Statistical Methods. 6th editor. Iowa State University Press, Ames, IA.

35. Oppenheimer, J. H., and H. L. Schwartz. 1985. Stereospecific transport of triiodothyronine from plasma to cytosol and from cytosol to nucleus in rat liver, kidney, brain, and heart. J. Clin. Invest. 75:147-154.

36. Wartofsky, L., and K. D. Burman. 1982. Alterations in thyroid function in patients with systemic illness: the "euthyroid sick syndrome." Endocr. Rev. 3:164-217.

37. Larsen, P. R., J. E. Silva, and M. M. Kaplan. 1981. Relationships between circulating and intracellular thyroid hormones: physiological and clinical implications. Endocr. Rev. 2:87-102.

38. St. Germain, D. L. 1988. The effects and interactions of substrates, inhibitors, and the cellular thiol-disalfide balance on the regulation of type II iodothyronine 5'-deiodinase. Endocrinology. 122:1860-1868.

39. Samuels, H. H., and J.S. Tsai. 1974. Thyroid hormone action: demonstration of similar receptors in isolated nuclei of rat liver and cultured $\mathrm{GH}_{1}$ cells. $J$. Clin. Invest. 53:656-659.

40. Koerner, D., H. L. Schwartz, M. I. Surks, J. H. Oppenheimer, and E. C. Jorgensen. 1975. Binding of selected iodothyronine analogues to receptor sites of isolated rat hepatic nuclei: high correlation between structural requirements for nuclear binding and biological activity. J. Biol. Chem. 250:6417-6423.

41. Samuels, H. H., J. S. Tsai, J. Casanova, and F. Stanley. 1974. Thyroid hormone action: in vitro characterization of solubilized nuclear receptors from rat liver and cultured GH cells. J. Clin. Invest. 54:853-865.

42. Evans, R. M. 1988. The steroid and thyroid hormone receptor superfamily. Science (Wash. DC). 240:889-895.

43. Thompson, C. C., C. Weinberger, R. Lebo, and R. M. Evans. 1987. Identification of a novel thyroid hormone receptor expressed in the mammalian central nervous system. Science (Wash. DC). 237:1610-1614.

44. Sap, J., A. Munoz, K. Damm, Y. Goldberg, J. Ghysdael, A. Leutz, H. Beug, and B. Vennstrom. 1986. The c-erb-A protein is a high-affinity receptor for thyroid hormone. Nature (Lond.). 324:635-640.

45. Nakai, A., S. Seino, A. Sakurai, I. Szilak, G. I. Bell, and L. J. DeGroot. 1988. Characterization of a thyroid hormone receptor expressed in human kidney and other tissues. Proc. Natl. Acad. Sci. USA. 85:2781-2785.

46. Murray, M. B., N. D. Zilz, N. L. McCreary, M. J. MacDonald, and H. C. Towle. 1988. Isolation and characterization of rat $\mathrm{CDNA}$ clones for two distinct thyroid hormone receptors. J. Biol. Chem. 264:12770-12777.

47. Weinberger, C., C. C. Thompson, E. S. Ong, R. Lebo, D. J. Gruol, and R. M. Evans. 1986. The c-erb-A gene encodes a thyroid hormone receptor. Nature (Lond.). 324:541-646. 